\title{
ANALISIS PENANGANAN KONFLIK ANTAR ORGANISASI KEMASYARAKATAN DI SUMATERA UTARA (MEDAN) DAN JAWA TENGAH (SURAKARTA)
}

\author{
Denny Zainuddin \\ Badan Penelitian dan Pengembangan Hukum dan HAM \\ Kementerian Hukum dan HAM RI \\ H.R. RasunaSaid Kav. 4-5 Kuningan Jakarta Selatan Kode Pos 12940 \\ Email: denny.zai@gmail.com
}

Tulisan Diterima: 15-03-2016 Direvisi: 27-04-2016 Disetujui: 14-07-2016

\begin{abstract}
Abstrak
Organisasi Kemasyarakatan hadir, tumbuh dan berkembang sejalan dengan sejarah perkembangan bangsa. Dalam sejarah perjuangan kemerdekaan negara Republik Indonesia, Ormas merupakan wadah utama dalam pergerakan kemerdekaan, pada satu sisi, Ormas merupakan sebuah bentuk kebebasan fundamental yang dimiliki oleh setiap individu baik dalam kerangka etika maupun legal, yang dilindungi dan dijamin pelaksanaannya oleh negara. Namun pada sisi lain, pelaksanaan kebebasan fundamental tersebut justru ditengarai memiliki dampak negatif, yakni menabrak batasbatas keajegan dan ketertiban sosial masyarakat Indonesia.

Penelitian ini melihat kebijakan pemerintah daerah dalam mengatasi konflik antar organisasi massa. Adapun pokok masalah ini diurai dalam beberapa pertanyaan, yaitu bagaimanakah dinamika konflik antar Ormas yang terjadi dan apa saja faktor penyebabnya, Kebijakan apa saja yang telah keluarkan oleh Pemerintah Daerah dalam rangka pengananan konflik antar Ormas, Bagaimana pengaruh kebijakan Pemda terhadap pengananan konflik antar Ormas.

Penelitian ini dianallisis dengan menggunakan teori mobilisasi sumber daya dan analisis circle of conflict, untuk mendapatkan jawaban bagaimana Konflik Ormas yang terjadi di Sumatera Utara dan Jawa tengah (Solo) dan bagaimana penanganan konflik oleh Pemerintah di kedua lokasi tersebut.

Penelitian ini menilai bahwa Pemda masih secara parsial menangani potensi konflik antar Ormas. Kebijakan yang ada masih bersifat administratif ketimbang sepenuhnya memberdayakan Ormas dalam mencapai tujuan bersama.
\end{abstract}

Kata kunci: Pemerintah, konflik, Ormas

\begin{abstract}
Civil society organizations present, grow and develop in line with the historical development of the nation. In the history of the struggle for freedom in Indonesia, CSOs are the main container in the independence movement, mass is a form of the fundamental freedoms of every individual in both the ethical and legal framework, which is protected and guaranteed execution by the state. the implementation of the fundamental freedoms it is considered to have a negative impact, namely crashing boundaries and social order of Indonesian society. The research looked at government policy in resolving the conflict between CSOs. As this subject is broken down into several questions, namely how the dynamics of the conflict between CSOs happened and what are the causes, any policy that has been issued by the local government in order from administration of conflict between CSOs, How to influence the Government's policies from administration of conflicts among CSOs. This study in anallisis by using the theory of resource mobilization and the circle of conflict analysis, to get the answer to how conflicts CSOs that happened in North Sumatra and Central Java (Solo) and how to deal with conflict by the Government at both locations. The study assessed that the existing policy is still an administrative nature rather than fully empowering organizations to achieve common goals.
\end{abstract}

Keywords: government, conflict, CBOs 


\section{PENDAHULUAN}

\section{Latar Belakang}

Penelitian ini menggambarkan penanganan konflik antar organisasi kemasyarakatan (Ormas) yang terjadi di dua lokasi yaitu Kota Medan dan Surakarta. Dalam kaitannya dengan isu tersebut, ruang lingkup hak asasi manusia yang menjadi dasar dalam penelitian ini diantaranya adalah: hak setiap orang atas rasa aman dan tentram, serta hak atas perlindungan terhadap ancaman ketakutan untuk berbuat atau tidak berbuat sesuatu. Beranjak dari hak atas rasa aman tersebut, penelitian ini mencoba menerapkan teori mobilisasi sumber daya oleh E.Canel yang jika dikaitkan dengan fenomena organisasi kemasyarakatan dapat diartikan sebagai penjelasan atas kapabilitas suatu gerakan sosial oleh masyarakat sipil untuk mengarahkan sumber daya yang dimilikinya (politik, sosial, dan moral), dan mengarahkannya kepada institusi kekuasaan negara dalam bentuk tekanan atau tuntutan. ${ }^{1}$

Penaganan konflik tidak dapat lepas dari kebijakan publik yang merupakan suatu proses untuk menilai seberapa jauh suatu kebijakan publik dapat membuahkan hasil, yaitu dengan membandingkan antara hasil yang diperoleh dengan tujuan atau target kebijakan publik yang ditentukan. ${ }^{2}$ James Andeson membagi evaluasi implementasi kebijakan publik menjadi tiga tipe, yaitu: Pertama, evaluasi kebijakan publik yang dipahami sebagai kegiatan fungsional. Kedua, evaluasi yang memfokuskan kepada bekerjanya kebijakan. Ketiga, evaluasi kebijakan sistematis yang melihat secara obyektif program-program kebijakan yang ditujukan untuk mengukur dampaknya bagi masyarakat dan sejauh mana tujuan-tujuan yang ada telah dinyatakan telah dicapai. $^{3}$

Republicanism: A Theory of Freedom and Governement berpendapat bahwa:The authorities will exercise arbitrary power if the decisions they make can be based on their private, perhaps sectional, interests or on their

1 Lihat.Muhamad Haripin. 2013. Reformasi Sektor Keamanan Pasca Orde Baru. Hal.31

2 Joko Widodo, Analisis Kebijakan Publik, (Jakarta: Bayumedi, 2008), h. 112.

3 Budi Winarno, Teori dan Proses Kebijakan Publik, (Yogyakarta, Media Pressindo, 2002), h. 168 private, perhaps sectional, ideas as to what their brieftheir brief qua legislator, administrator, or judgerequires. If private inclination or private opinion can rule, then people will live at the mercy of the officials. The authorities will have the power, not just to interferethat is inherent in a system of lawbut to interfere on a relatively arbitrary basis. They will be in a position where they dominate ordinary people and, this being a matter of common knowledge, they will be in a position where ordinary people may be expected to have to bow and scrape to them. ${ }^{4}$

Mengingat secara teoritis, kebijakan publik secara umum didefinisikan sebagai studi tentang keputusan dan aktivitas pemerintah yang didesain untuk mengatasi permasalahan yang menjadi perhatian publik, maka secara fundamental kepentingan dan kontekstualisasi kehidupan sosial masyarakat di suatu tempat patut menjadi dasar kebijakan, yang disampaikan melalui partisipasi masyarakat yang efektif.

\section{Rumusan Masalah}

Pokok masalah dalam penelitian ini adalah kebijakan pemerintah daerah dalam mengatasi konflik antar organisasi massa. Adapun pokok masalah ini diurai dalam beberapa pertanyaan berikut ini: (i) Bagaimanakah dinamika konflik antar Ormas yang terjadi dan apa saja faktor penyebabnya; (ii) Kebijakan apa saja yang telah keluarkan oleh Pemerintah Daerah dalam rangka pengananan konflik antar Ormas?

\section{Tujuan}

Memetakan faktor-faktor yang menyebabkan konflik antar Ormas. Mengetahui kebijakan pemerintah daerah dalam penanganan konflik antar Ormas. Mengungkap pengaruh kebijakan Pemerintah Daerah terhadap pengananan konflik antar organisasi kemasyarakatan.

\section{Metodologi Penelitian}

Penelitian ini adalah penelitian lapangan (field research) dengan metode kualitatif ${ }^{5}$,

4 Philip Pettit, Republicanism: A Theory of Freedom and Government, 2002, Clarendon Press, Oxford, hlm. 183-184.

5 Noong Muhajir, Metodologi Penelitian Kualitatif (Yogyakarta: Rake Sarasin, 2000), 341. Consuelo G. Sevilla, dkk.,Pengantar Metodologi Penelitian (Jakarta: UI Press, 2006), 73-76. 
penelitian ini menggunakan metode studi kasus, seperti: konflik Ormas keagamaan dengan warga masyarakat di Kota Surakarta dan konflik antar Ormas kepemudaan di Kota Medan beserta konflik-konflik lainnya.

\section{PEMBAHASAN}

Konflik Sosial adalah perseteruan dan/atau benturan fisik dengan kekerasan antara dua kelompokmasyarakatataulebihyangberlangsung dalam waktu tertentu dan berdampak luas yang mengakibatkan ketidakamanan dan disintegrasi sosial sehingga mengganggu stabilitas nasional dan menghambat pembangunan nasional. Penanganan konflik adalah serangkaian kegiatan yang dilakukan secara sistematis dan terencana dalam situasi dan peristiwa baik sebelum, pada saat, maupun sesudah terjadi konflik yang mencakup pencegahan konflik, penghentian konflik, dan pemulihan pasca konflik. ${ }^{6}$

Gareth R. Jones mendefinisikan konflik organisasi sebagai "perbenturan yang muncul kala perilaku mencapai tujuan tertentu yang ditunjukan suatu kelompok dirintangi atau digagalkan oleh tujuan kelompok lain. ${ }^{7}$ Rahim menyebut konflik sebagai proses interaktif bukan dengan maksud hendak membatasi kemungkinan konflik di dalam diri individu, karena seringkali seseorang mengalami konflik dengan dirinya sendiri. ${ }^{8}$ Lebih lanjut konflik hadir antar individu, kelompok, atau departemen. Konflik pun dapat terjadi diantara mereka yang punya tugas wewenang berbeda bahkan kolegakolega kerja mereka sendiri. ${ }^{9}$

Organisasi Kemasyarakatan yang selanjutnya disebut Ormas adalah organisasi yang didirikan dan dibentuk oleh masyarakat

Joseph A. Maxwell, Qualitative Research Design an Interactive Approach (London, Sage Publication, 2005), Koentjaraningrat, Metode-metode Penelitian Masyarakat cet. ke-14(Jakarta: Gramedia, 1997).

$6 \quad$ Lihat Pasal 1 ayat 1-2 Undang-Undang No. 7 Tahun 2012 tentang Penanganan Konflik Sosial

7 Gareth R. Jones, Organizational Theory, Design, and Change, 5th Edition (New Delhi: Dorling Kindersley, 2009) p.408.

8 M. Afzalur Rahim, Managing Conflict in Organizations, 4th Edition (New Jersey: Transaction Publishers, 2011) p.16.

9 Ian Brooks, Organisational Behaviour: Individuals, Groups, and Organisations, 3rd Edition (Delhi: Dorling Kindersley, 2006) p.234. secara sukarela berdasarkan kesamaan aspirasi, kehendak, kebutuhan, kepentingan, kegiatan, dan tujuan untuk berpartisipasi dalam pembangunan demi tercapainya tujuan Negara Kesatuan Republik Indonesia yang berdasarkan Pancasila. ${ }^{10}$

Organisasi Masyarakat adalah perkumpulan sosial yang dibentuk oleh masyarakat, baik yang berbadan hukum maupun yang tidak berbadan hukum secara sukarela atas dasar kesamaan kegiatan, profesi, tujuan yang berfungsi sebagai sarana partisipasi masyarakat dalam pembangunan bangsa dan negara. Sebagai makhluk yang selalu hidup bersama-sama, manusia membentuk organisasi sosial untuk mencapai tujuan-tujuan tertentu yang tidak dapat mereka capai sendiri.

Robert Edelmann, Henry L. Tosi and Neal P. Mero mengidentifikasi sejumlah faktor pemicu konflik. Faktor-faktor tersebut mereka kelompokan ke dalam 3 kategori utama yaitu: (1) Perbedaan Karakter Individu; (2) Kondisi Situasional; dan (3) Kondisi Keorganisasian. ${ }^{11}$ Lebih lanjut lagi pengidentifikasian konflik dikaitkan dengan teori mobilisasi.

\section{Teori Mobilisasi Sumberdaya}

Berdasarkan teori mobilisasi sumber daya oleh E.Canel di atas, penelitian ini mendasarkan analisis dari beberapa asumsi teoretis sebagai berikut:

1. Gerakan sosial harus dipahami dalam kerangka model konflik aksi kolektif;

2. Tidak ada perbedaan mendasar antara aksi-aksi kolektif institusional dan noninstitusional;

3. Baik aksi institusional maupun noninstitusional berisikan serangkaian konflik kepentingan yang terbangun dalam sistem relasi kekuasaan yang terlembagakan;

4. Gerakan sosial melibatkan cita-cita rasional berbagai kepentingan melalui kelompokkelompok yang saling berkompetisi;

10 Undang-Undang Republik Indonesia Nomor 17 Tahun 2013 Tentang Organisasi Kemasyarakatan

11 Henry L Tosi and Neal P. Mero, The Fundamentals of Organizational Behavior: What Managers Need to Know (Malden, Massachussetts: Blacwell Publishing, 2003) p.189-91. 
5. Tujuan dan penderitaan, konflik dan tanding, semuanya hadir secara inheren dalam seluruh relasi kekuasaan;

6. Formasi gerakan sosial ditentukan oleh perubahan sumberdaya, organisasi, dan kesempatan untuk aksi kolektif;

7. Keberhasilan dan keefektifan aksi kolektif dipahami dalam arti keuntungan material namun bukan berarti profit atau aktornya dikenal sebagai tokoh politik;

8. Mobilisasi orang dalam gerakan sosial kontemporer berukuran skala besar yang merupakan hasil dari teknik komunikasi terkini, birokratisasi organisasi dan dorongan serta inisiatif utilitarian. ${ }^{12}$

Berdasarkan asumsi tersebut, penelitian ini memandang fenomena konflik antar Ormas ke dalam beberapa aspek, meliputi: perkembangan Ormas, kondisi sosial kemasyarakatan, konflik Ormas serta penanganannya. Untuk kebutuhan penelitian ini, rangkaian aspek tersebut akan coba dijawab melalui deskripsi data lapangan untuk mendapatkan gambaran konflik antara organisasi kemasyarakatan.

\section{PERKEMBANGAN ORMAS}

Provinsi Sumatera Utara (Sumut) memiliki berbagai macam Ormas yang berdiri dan berkembang menjadi berbagai Ormas yang besar. Jumlah Ormas yang berada di Sumut saat ini mencapai 5.000 Ormas, yang membuat provinsi ini menjadi provinsi dengan Ormas terbanyak di seluruh Indonesia. Jumlah itu pun merupakan data Ormas yang mendaftarkan keberadaannya di pemerintah. Berdasarkan data kualitatif yang didapat oleh penelitian, diperkirakan jumlah Ormas di Sumut lebih dari 5.000 Ormas, karena diduga banyak organisasi yang tidak mendaftarkan diri ke pemerintah daerah. Adapun jumlah Ormas, LSM, yayasan, dan lainnya yang terdaftar secara resmi di Pemprov Sumut berjumlah sekitar 1.700-an organisasi.

Dipahami oleh para informan bahwa kehadiran Ormas di tengah masyarakat diperlukan sebagai penyeimbang, dalam arti bahwa pekerjaan pemerintah dapat diawasi

12 Muhamad Haripin. 2013. Reformasi Sektor Keamanan Pasca Orde Baru. Hal.37 oleh Ormas tersebut. Pertumbuhan Ormas saat ini bukan hanya untuk menjadi alat penyeimbang, tetapi juga untuk kepentingan. "untuk membedakan visi misi dari Ormas ini, dapat dilihat dari bertahannya Ormas di dalam masyarakat. Cepat tumbuh dan berkembang, setelah itu menghilang, ada kemungkinan Ormas tersebut berdiri karena faktor kepentingan. Tetapi, bila suatu Ormas mampu bertahan, ada kemungkinan visi misinya untuk memajukan masyarakat.

Pemerintah Kota Surakarta dalam hal ini diwakili oleh Badan Kesbangpol dalam wawancara menyampaikan bahwa Ormas di Kota Surakarta sejumlah sekitar 400-an Ormas dengan berbagai macam kategori aktivitas, meliputi: keagamaan, pendidikan, serta kegiatan sosial kemasyarakatan. Aktivitas ke-Ormas-an di Kota Surakarta tidak dapat dilepaskan dari konteks geografis Surakarta dalam Karesidenan Surakarta (Surakarta Raya) yang meliputi wilayah-wilayah lain disekitar Surakarta, seperti Sukoharjo, Karanganyar, dan lain-lain. Dengan demikian, terdapatbanyakOrmasyangmelakukan aktivitas di Kota Surakarta yang sebenarnya berdomisili di luar kota. Dari sisi pendaftaran Ormas, terdapat pula kecenderungan bahwa masyarakat mendirikan Ormas dengan tujuan mendapatkan bantuan sosial (dana hibah) dari pemerintah kota semata.

Deskripsi tentang perkembangan Ormas di dua lokus penelitian ini mencerminkan sebuah pergeseran aksi kolektif masyarakat yang terjadi utamanya pasca turunnya rezim 'orde baru' di bawah pemerintahan Presiden Soeharto. Kebebasan dan kesadaran kolektif untuk berserikat, yang pada masa lalu sempat dikekang, kini kian menonjol dengan segala bentuk serikat dan kegiatannya. Terlepas dari fenomena pragmatisme ke-Ormas-an, yang terindikasi dari munculnya Ormas yang hanya mencari dana hibah dari pemerintah, pada prinsipnya Ormas di dua lokus penelitian merupakan sebuah bentuk mobilisasi massa yang merayakan kebebasannya sebagai saluran aspirasi kepada pemerintah. Selanjutnya, deskripsi ini juga menyampaikan sebuah premis bahwa perkembangan Ormas di dua lokus penelitian, berikut berbagai potensi konflik antar Ormas, merupakan produk dari serangkaian 'konflik kepentingan dalam relasi kuasa yang terlembagakan'. 


\section{Kondisi Sosial}

Kondisi yang ada di Kota Medan, memiliki kompleksitas yang tinggi dalam dari sudut pandang faktor ekonomi. Sulitnya mencari lapangan pekerjaan menjadi penentu utama, sehingga membuat Ormas semakin marak dan membesar di Sumut, terutama Ormas yang memiliki visi dan misi pemberdayaan masyarakat. Data kualitatif di lapangan juga menunjukkan bahwa potensi konflik yang terjadi dalam struktur sosial masyarakat yang bersifat ekonomi tersebut juga masuk kedalam ranah politis. Dalam situasi tersebut, pihak yang terlibat dalam konflik akan memperkuat solidaritas antar anggota kelompok mereka.

Kondisi sosial di Provinsi Jawa Tengah, dalamhal ini Kota Surakarta, memilikikarakteristik yang berbeda dengan Kota Medan. Berangkat dari fakta yang ada bahwa di Surakarta, di satu sisi, dikenal sebagai kota yang rawan kerusuhan, namun disisi lain, tidak satu pun dari konflik dan kerusuhan di atas terjadi dalam skala masif. Konflik yang sering terjadi di Surakarta diduga kuat berlatar belakang sentimen keagamaan dan premanisme.

Dari gambaran tersebut serta mengingat 'formasigerakan sosial ditentukanoleh perubahan sumberdaya, organisasi, dan kesempatan untuk aksi kolektif', maka dapat diasumsikan bahwa fenomena ke-Ormas-an di Kota Medan didorong secara dominan oleh faktor ekonomi, sedangkan di Kota Surakarta gerakan sosial kontemporer banyak diisi oleh semangat puritan keagamaan.

\section{Konflik Ormas dan Penanganannya}

Lembaga Kepolisian, petugas lapangan Kepolisian, Badan Kesatuan Kebangsaan dan Politik Provinsi Sumatera Utara, Badan Kesatuan Kebangsaan dan Politik Kota Medan, Ormas Pemuda Pancasila dan Ormas Ikatan Pemuda Karya, dalam kegiatan ini menjadi sumber pencarian data untuk membahas apa saja terkait dengan kebijakan, konflik, dan pola penganan yang dilakukan untuk mengatasi konflik yang terjadi. Hasil yang didapat dari kegiatan pengumpulan data penelitian ini dapat dirangkum sebagai berikut:

Intelkam kepolisian Sumut menyatakan bahwa dalam melakukan penanganan, pihaknya mengerahkan pasukan pengurai masa untuk memisahkan bentrok yang terjadi antara
Pemuda pancasila dengan Ikatan Pemuda Karya. Salah satu upaya yang dilakukan oleh pihak kepolisian untuk menyelesaikan bentrokan yang terjadi ialah dengan melibatkan tokoh masyarakat. Adapun pihak Pemerintah Provinsi/ Kota hanya melakukan pemantauan terhadap perkembangan bentrokan, sedangkan yang selalu berada pada lokasi kejadian meliputi Polisi, Camat, dan Lurah.

Konflik antar Ormas terjadi dan berulang tersebut disebabkan perekonomian (Pengangguran, Pemuda, dan perebutan wilayah, yaitu memperebutkan wilayah kekuasaan). Namun bentrok yang terjadi tidak pernah sampai kepada bentrok fisik, masih pada tahapan lempar-lemparan batu dan pembakaran property seperti kendaraan dan simbol Ormas.

Pihak kepolisian memfasilitasi mediasi untuk memyelesaikan dengan cara damai melalui memanggil masing pihak yang berseteru untuk bertemu dan selalu didamping oleh pihak kepolisian. Proses hukum terus berjalan berdasarkan pengaduan dari pihak Ormas yang dirugikan.

Badan Kesatuan Bangsa, Politik dan Perlindungan Masyarakat Kota Medan, Berdasarkan hasil wawancara, konflik yang terjadi antar Ormas bukanlah konflik antar organisasi, melainkan konflik antar pemuda anggota Ormas.Secara khusus pemerintah daerah belum membuat peraturan untuk penanganan konflik, namun pemerintah kota membuat road map dalam penyikapi konflik di daerah. Sehingga penanganan konflik masih bersifat insedentil dan melibatkan Muspida dan secara khusus meminta pihak kepolisian dalam penanganan dan mencari solusi terhadap konflik yang terjadi.

Berdasarkan hasil wawancara dengan Lurah Medan Petisah, pihak kelurahan tidak secara langsung terlibat dalam melerai konflik antar Ormas yang terjadi. Hal tersebut dikarenakan keterbatasan sarana dan prasarana yang dimiliki oleh pihak kelurahan. Peran Kelurahan dalam menyikapi konflik yang terjadi hanya pada tahap melaporkan kepada pihak kepolisan setiap kejadian yang terjadi di wilayah kelurahan tersebut. Pihak kelurahan mengungkapkan pernah mengajukan anggaran terkait kegiatan sosialisasi dengan tujuan meredam terjadinya konflik, namun permohonan anggaran tersebut 
ditolak dengan alasan kegiatan tersebut merupakan kegiatan dari Kesbangpol.

Bakesbangpol Sumatera Utara selalu berkoordinasi dengan Muspida dalam upaya deteksi dini terjadinya konflik dan mencari solusi untuk mengantisipasi konflik. Kesbangpol Sumatera Utara melakukan pendataan dan pendaftaran ORMAS dan melakukan teguran kepada ORMAS yang tidak mendaftarkan kepada kesbangpol.

Upaya penanganan konflik sosial pemerintah kota medan melakukan penguatan peranserta tokoh agama dan tokoh masyarakat dalam menyebarluaskan nilai-nilai multikultural kerukunan dan toleransi, hal tersebut tercatum dalam rencana aksi terpadu penganan gangguan keamanan dalam negeri pemerintah Kota Medan tahun 2013. Namun dalam upaya menyelesaikan konflik yang terjadi pihak Bakesbangpol, tokoh masyarakat, dan tokoh agama tidak secara langsung turut serta mendamaikan ataupun melakukan mediasi, upaya perdamaian dan mediasi sepenuhnya diserahkan kepada kepolisian.

Konflik yang terjadi di Sumatera Utara antara Pemuda Pancasila dengan Ikatan Pemuda Karya dipicu karena adanya kesalah-pahaman antar anggota, namun hal tersebut tidak diakui sebagai konflik antar organisasi. Setiap yang muncul selalu dilimpahkan kepada pihak kepolisian untuk menempuh proses hukum. Setiap terjadinya konflik, pimpinan Ormas dipertemukan untuk dimediasi oleh kepolisian untuk mencapai kata damai dan tersebut tidak meluas.

Ketelibatan Polda dalam hal ini Intelkam dalam pencagahan dan pendamaian tidak melibatkan pihakpemerintah daerah, dikarenakan konflik yang terjadi di asumsikan masih dalam skala kecil.Pihak polda selain melakukan upaya penanganan konflik dan pendamaian, juga melakukan sosialisasi dalam upaya pencegahan dengan cara meningkatkan patroli.

Berdasarkan hasil wawancara yang dilakukan, pengurus Ormas pemuda pancasila bukanlah organisasi preman seperti yang dinilai oleh masyarakat, Pemuda Pancasila memiliki berbagai kegiatan sosial dan merangkul pemuda untuk dapat berkembang dan berkehidupan. Namun jika terjadi perseteruan antara anggota Ormas, hal tersebut bukanlah konflik antar Ormas. Setiap terjadi konflik pihak pemuda pancasila melimpahkan kepada pihak kepolisian untuk diproses secara hukum yang berlaku. Hal yang sama disampaikan oleh pengurus Ormas Ikatan Pemuda Karya. Kegiatan yang dilakukan lebih banyak untuk kegiatan sosial kemasyarakatan, namun tidak dapat dipungkiri jika dalam kenyataan dilapangan terjadi gesekan antar anggota Ormas.

Berdasarkan hasil wawancara yang dilakukan di Kota Surakarta konflik Ormas didasari oleh isu terorisme dan radikalisme agama menjadi fenomena sekaligus tantangan baru bagi pemerintah daerah dalam meramu hubungan ke-Ormas-an di Kota Surakarta.

Kepolisian Resort Kota Surakarta, dalam wawancara menyampaikan bahwa, "tidak terdapat konflik antar Ormas di Surakarta tidak ditemukan, karena aktor dalam beberapa konflik kekerasan yang terjadi dalam kapasitas individu bukan atas nama kelompok". Akar konflik antar Ormas seringkali terjadi karena faktor-faktor yang bersifat individual dan bukan terorganisir. Ormas yang memiliki potensi untuk berkonflik berlatar-belakang ideologi agama, dalam hal ini Islam.

Perilaku kekerasan yang dilakukan oleh oknum Ormas tertentu bisa terjadi karena pemahaman ideologi dalam Ormas keanggotaannya. Tipikal Ormas dengan ideologi Islam di Surakarta berbeda dengan kelompok masa Islam di Jawa Timur. Patronase di tengah kelompok Islam di Surakarta ditujukan pada ketua masing-masing Ormas, sehingga tidak diarahkan pada tokoh agama tertentu (di Surabaya, patronase kelompok diarahkan pada kyai atau ustadz).

Pada kesempatan lain, Corps Hizbullah Yon 99 Divisi Sunan Bonang yang menjadi informan penelitian merupakan salah satu Ormas yang bergerak di bidang keagamaan dengan ratusan jumlah anggota. Kegiatan Ormas ini meliputi aktivitas keagamaan (seperti pengajian rutin) radio, dan saat ini sedang merambah ke media televisi sebagai salah satu bentuk dakwah. Hizbullah sebagai Ormas Islam yang memiliki skala nasional berprinsip bahwa religiusitas yang dimiliki oleh organisasi di dalamnya terkandung semangat nasionalisme atas utuhnya Negara Kesatuan Republik Indonesia (NKRI). Landasan religius serta pandangan tentang NKRI tersebut 
memiliki implikasi pada cara-cara organisasi dalam menangani problematika sosial, khususnya di Kota Surakarta.

Pengalaman keikutsertaan Hizbullah dalam konflik-konflik sosial di beberapa wilayah di Indonesia secara langsung memiliki pengaruh terhadap tingkat agresivitas organisasi ini terhadap sosial di Surakarta. Sweeping pada saat bulan Ramadhan, pemboman terhadap tempat hiburan di Surakarta pada tahun 2005, menjadi beberapa catatan keterlibatan Ormas ini dalam konflik kekerasan di Kota Surakarta. Argumentasi organisasi dalam keterlibatan dalam kekerasan ialah adanya anggapan bahwa organisasi berkewajiban untuk turut serta dalam menjamin keamanan dan ketertiban di tengah masyarakat Surakarta.

Faktor yang memengaruhi dipahami dalam dua arah: dari tataran negara, pihak pemerintah dan aparat keamanan dianggap gagal dalam memenuhi tanggung jawab untuk memelihara keamanan dan ketertiban serta akhlak warga yang tidak sesuai dengan ajaran agama Islam. Premanisme diakui oleh Hizbullah sebagai fenomena sosial yang hidup di Surakarta. Pembagian kekuasaan preman terdapat di beberapa wilayah di Kota Surakarta, misalnya: kelompok DMC, dan lain sebagainya.

Fenomena munculnya kelompok-kelompok Islam, yang menyebar dalam jumlah yang relatif kecil ( \pm 50 orang), juga menjadi fenomena baru di Surakarta. Masyarakat Surakarta menyebut anggota Ormas radikal kanan ini dengan sebutan 'laskar'. Pecahnya konflik antara 'laskar' dengan preman disebabkan oleh faktor struktural yakni: dari tataran negara, pemerintah daerah serta kepolisian tidak bersikap dengan tegas terhadap penegakan hukum dan pemeliharaan ketertiban di kota. Pada sisi lain, di tataran Ormas, terdapat banyak Ormas 'liar' yang gerah dengan acuhnya sikap pemerintah terhadap sosial di kota.

Front Pembela Islam Surakarta menyampaikan bahwa konflik ke-Ormas-an di Kota Surakarta, utamanya dari perspektif Ormas Islam, justru rentan terjadi di antara Ormas Islam itu sendiri. Berbagai intrik antar kalangan, seperti tuduhan negatif, pengkafiran, dan lain sebagainya digunakan sebagai metode untuk menyudutkan pihak-pihak tertentu.
Pencegahan Konflik di antara Organisasi Kemasyarakatan di Sumatera Utara dan Jawa tengah

Konflik di atas dapat mencerminkan bagaimana gangguan keamanan dan ketertiban di antara Organisasi Kemasyarakatan yang dapat deskripsikan melalui analisis Circle Of Conflict. ${ }^{13}$ Konflik antar Ormas dapat dilihat dengan pola di atas, setiap konflik yang terjadi dianalisa dengan empat poin meliputi: masalah hubungan, data, struktural, dan perbedaaan nilai.

\section{ANALISIS CIRCLE OF CONFLICT}

Setiap kelompok dalam satu organisasi, dimana di dalamnya terjadi interaksi antara satu dengan lainnya, memiliki kecenderungan timbulnya konflik. Dalam organisasi kemasyarakatan terjadi interaksi, baik antara kelompok dengan kelompok, kelompok dengan individu, maupun individu dengan individu antar organisasi kemasyarakatan. Situasi tersebut seringkali dapat memicu terjadinya konflik. Konflik sangat erat kaitannya dengan perasaan manusia, termasuk perasaan diabaikan, tidak dihargai, disepelekan, ditinggalkan, dan juga perasaan kesal karena persaingan. Perasaanperasaan tersebut sewaktu-waktu dapat memicu timbulnya kemarahan. Keadaan tersebut akan mempengaruhi seseorang dalam melaksanakan kegiatannya secara langsung, dan dapat menurunkan cita-cita awal pembentukan Ormas.

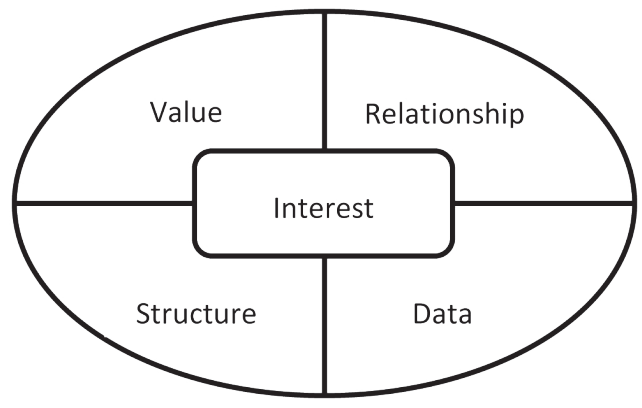

Seiring berjalannya waktu, di dalam organisasi kerap terjadi konflik. Baik konflik internal maupun konflik eksternal antar organisasi. Konflik yang terjadi kadang kala terjadi karena problem kecil. Namun justru dengan hal yang kecil itulah sebuah organisasi dapat bertahan lama atau tidak. Mekanisme

13 Moore, Christopher W. 1996. The mediation process: practical strategies for resolving conflict. Second edition. San Francisco: Jossey-Bass, hlm 60-61. 
ataupun manajemen konflik yang diambil pun sangat menentukan posisi organisasi sebagai lembaga yang menjadi payungnya. Kebijakankebijakan dan metode komunikasi yang diambil sangat memengaruhi keberlangsungan sebuah organisasi dalam memertahankan anggota dan segenap komponen di dalamnya.

Sumatera Utara, konflik yang terjadi merupakan mendasar yaitu ekonomi yang menjadi pemicu terjadinya bentrokan fisik. Ketika dikonfirmasi kepada organisasi yang menangungi pihak yang berkonflik hal tersebut disangkal bahwa itu adalah konflik antar organisasi, namun apa bila kita melihat asumsi yang didapat dari teori mobilisasi sumber daya oleh E.Canel, yang menyatakan bahwa tidak ada perbedaan mendasar antara aksi-aksi kolektif institusional dan non-institusional dan baik aksi institusional maupun non-institusional berisikan serangkaian konflik kepentingan yang terbangun dalam sistem relasi kekuasaan yang terlembagakan.

Asumsi tersebut menyatakan bahwa setiap individu yang terdapat dalam organisasi kemasyarakatan merupakan bagian yang tidak terpisah dari organisasi. Artinya setiap tindakan yang dilakukan baik secara individu maupun secara berkelompok (organisasi) merupakan suatu tindakan dibawah tanggung jawab organisasi. Berdasarkan asumsi tersebut pula maka setiap organisasi kemasyarakatan harus melakukan pembinaan dan pemantauan terhadap setiap tindakan yang dilakukan oleh anggotanya.

Berdasarkan asumsi dari teori mobilisasi sumber daya oleh E.Canel tersebut, asumsi tersebut dapat diperkuat dengan Analisis Circle Of Conflict untuk melihat masalah hubungan, data, struktural, dan perbedaan nilai.

Pertama data (informasi). Salah satu penyebab dari masalah ini adalah adanya informasi hilang atau informasi yang dimiliki kurang,atau adanya pandangan yang berbeda tentang informasi. Interpretasi yang berbeda dari data yang diterima menjadi berbeda dengan data dinilai. Titik kunci di sini adalah bahwa data atau informasi adalah akar masalahnya. Ormas di Kota Medan maupun Ormas yang berada di Surakarta kehadirannya di tengah masyarakat menjadi penyeimbang, dimana pekerjaan pemerintah diawasi oleh perkumpulan tersebut. Bagi masyarakat,Ormas dapat dijadikan sebagai wadah untuk menyampaikan aspirasinya. Tujuan yang dimiliki oleh Ormas tersebut sering diinterpretasikan berbeda oleh para anggotanya, utamanya ketika Ormas dijadikan sebagai alat untuk kepentingan. Bila tidak diperhatikan, berbagai Ormas yang ada terutama kepemudaan berpotensi menjadi alat untuk melegalisasikan keberadaan premanisme.

Kedua adalah struktural. Konflik struktural pada umumnya disebabkan oleh pola atau interaksi prilaku yang destruktif; kontrol, kepemilikan, dan distribusi sumber daya yang tidak setara; kekuasaan dan otoritas yang tidak setara; serta faktor-faktor geografis, fisik, dan lingkungan yang menghalangi kerjasama. Melihat kondisi yang ada di kota Medan dan kota Surakarta, Pemerintah Daerah belum secara optimal merangkul Ormas. Hal tersebut terwujud dengan tidak adanya pembinaan dan pengawasan terhadap kegiatan yang dilakukan oleh Ormas, dan setiap kali terjadi konflik maupun pasca konflik, pemerintah daerah tidak secara langsung melakukan upaya penanganan masalah. Secara geografis keberadaan Ormas radikal kanan berdomisili di luar kota Surakarta, hal tersebut yang menyebabkan pemerintah kota untuk melakukan pembinaan dan pemantauan setiap kegiatan Ormas, tindakan yang selama ini dilakukan oleh pemerintah kota Surakarta dalam rangka penanggulangan potensi konflik dengan cara mengadakan kegiatan yang bertema kebudayaan, hal tersebut bertujuan untuk menciptakan rasa kebersamaan di antara masyarakat. Sedangkan penanganan yang dilakukan di kota medan untuk penanganan konflik di lakukan dengan pendekatan kemanan dan ketertiban yang dilakukan oleh pihak kepolisian.

Pada posisi tersebut terdapat signifikansi pemerintah daerah dalam merumuskan dan melaksanakan kebijakan untuk menangani konflik antar Ormas. Sebagai bentuk Pemerintah Daerah berkewajiban untuk mengeluarkan kebijakan agar konflik tidak terjadi. Peran pemerintah daerah dalam menangani konflik antar Ormas merupakan titik krusial agar konflik tidak terjadi (berulang) dan tidak meluas sebagai konflik besar, baik kebijakan pencegahan, penghentian, dan maupun pemulihan paska konflik. 
Dalam implementasinya, kebijakan $\mathrm{Pe}$ merintah Kota dalam penyelesaian konflik bertumpu pada aparat kepolisian dalam upaya penanganan sampai kepada tahapan mediasi dan rekonsiliasi. Sehingga tidak sesuai dengan amanat Undang-undang untuk kepentingan penanganan Konflik Sosial.

Ketiga adalah hubungan. Kesalahan persepsi atau stereotip dari orang lain adalah penyebab umum dari konflik hubungan. Komunikasi yang buruk atau miskomunikasi seringkali menyebabkan perilaku negatif Ormas atau anggota Ormas terjadi berulang-ulang. Untuk permasalahan ini, poin pentingnya ialah bagaimana orang berhubungan satu sama lain dan interaksi perilaku mereka berkontribusi untuk menimbulkan masalah.

Permasalahan hubungan, terdapat antara kota medan dan kota Surakarta. Kota medan terdapat beberapa faktor yaitu rasa solidaritas organisasi, Konflik yang berulang, Tidak adanya hubungan baik anggota antar Ormas. Ketiga hal tersebut didukung dengan faktor ekonomi, sehingga memuncul kan berbagai macam konflik dengan Ormas lainnya. Sedangkan di Kota Surakarta konflik yang terjadi disebabkan adanya persingungan terhadap nilai-nilai agama dan Stereotipe terhadap Ormas (laskar) menimbulkan rasa curiga di tengah masyarakat yang menyebabkan tidak harmonisnya hubungan yang ada di masyarakat.

Keempat adalah nilai. Cara hidup yang berbeda, ideologi atau cara pandang adalah contoh bagaimana apa yang di nilai bisa menjadi bagian dari masalah. Memiliki kriteria yang berbeda untuk penelitian ide-ide adalah contoh lain. permasalahan ini adalah semua tentang apa yang menghargai orang dan jika mereka berada di lingkungan yang sama tentang nilainilai.

Konflik Ormas di Kota Medan jika di lihat dari permasalahan nilai, yang menjadi permasalahan adalah Ormas memiliki nilai yang harus di junjung martabatnya dan Faktor ekonomi sebagai dasar pemersatu pemahaman di dalam satu Ormas, kondisi yang terjadi di Kota Medan, Ormas yang memiliki anggota dengan jumlah besar menguasasi beberapa lokasi dan lokasi tersebut dijadikan lahan pencarian bagi para anggotanya, disinilah yang menyebabkan terjadinya konflik.
Konflik yang terjadi di kota Surakarta sudah berlangsung lama dan memiliki sejarah panjang tentang pertarung ideologi sejak masa persiapan kemerdekaan sampai masa revolusi orde lama. Adapun pertarungan ideologi tersebut antara radikal kiri, yakni kalangan komunis, dan radikal kanan, yakni kalangan Agama Islam. Persinggungan ideologi tersebut menyebabkan kerentanan konflik antar organisasi di Kota Surakarta.

Permasalahan yang terdapat dalam Circle Of Conflict adalah kepentingan. kepentingan adalah motivasi untuk tindakan. Contoh di kota Medan dan Kota Surakarta dianggap adanya persaingan aktual atas kepentingan yang sangat mendasar dan menjadi akar masalah. Di satu sisi mememiliki kepentingan terhadap faktor ekonomi dan di satu sisi memiliki kepentingan terhadap kebenaran ideologi agama, kedua faktor tersebut yang menyebabkan sering berulangnya konflik dan menimbulkan rasa tidak aman bagi masyarakat.

Lima permasalahan di atas, yang meliputi: data, struktur, hubungan, nilai-nilai dan kepentingan, merupakan akar penyebab potensial dari masalah yang berada di kedua lokasi. Adapun akar permasalahan yang ada perlu diberi titik tekan yang berbeda pada masingmasing lokus. Konflik Ormas di Kota Medan lebih menunjukkan aspek struktural sebagai akar permasalahan yang dominan, sedangkan di Kota Solo, aspek nilai yang lebih menonjol ketimbang aspek lainnya. Namun demikian, masing-masing lokasi memiliki kesamaan secara struktural, yakni pemerintah kota tidak memiliki kebijakan khusus dalam rangka pencegahan konflik yang melibatkan Ormas dengan Ormas maupun Ormas dengan masyarakat.

Berdasarkan sudut pandang yang berbeda konflik Ormas pun dapat ditimbulkan dari tidak semua Ormas terdaftar di pemerintah kota yang dalam hal ini adalah Bakesbangpol. Sedangkan dari hasil wawancara, masih banyak Ormas yang belum mendaftarkan atau melengkapi data organisasinya Bakesbangpol. Tindakan yang dilakukan kepada Ormas yang tidak terdaftar hanya sebatas melakukan teguran atau mengimbau kepada Ormas-Ormas yang belum terdaftar karena tidak ada sanksi yang signifikan terhadap Ormas tersebut. 


\section{PENUTUP}

\section{Kesimpulan}

Konflik antar Ormas kepemudaan di Kota Medan yang terjadi selama tahun 2012 sampai tahun 2013, diantaranya terjadi dikarenakan faktor perekonomian, namun terdapat juga faktor lainnya yang sifatnya sepele seperti persingungan perasaan. Faktor demikian kerap menyebabkan kekerasan dan perkelahian antar massa dalam skala besar. Konflik antar Ormas di Kota Surakarta yang terjadi dikarenakan faktor ideologi keagamaan radikal kanan. Konflik tersebut melibatkan perseteruan antara Ormas dengan masyarakat setempat. Kecenderungan munculnya konflik di kota Surakarta sangatlah besar dengan indikasi menguatnya stereotipe di masyarakat terhadap Ormas radikal kanan (laskar) yang menimbulkan rasa curiga di tengah masyarakat. Kondisi demikian dapat menyebabkan tidak harmonisnya hubungan yang ada di tengah masyarakat.

\section{Saran}

Pertama, Pemerintah kota belum tanggap terhadap potensi konflik antar organisasi kemasyarakatan.

Kedua, Pemerintah kota memerlukan Pemetaan konflik di masing-masing daerah dan pemetaan tersebut dapat didasarkan dari teori circle of conflict.

Ketiga, Secara khusus untuk Pemerintah Kota Medan, maka peta potensi konflik perlu dititik-tekankan pada aspek 'hubungan'. Sedangkan untuk Pemerintah Kota Surakarta, peta potensi konflik perlu memerhatikan secara lebih pada aspek 'nilai'.

\section{DAFTAR PUSTAKA}

Budi Winarno, Teori dan Proses Kebijakan Publik, (Yogyakarta, Media Pressindo, 2002).

Gareth R. Jones, Organizational Theory, Design, and Change, 5th Edition (New Delhi: Dorling Kindersley, 2009).

Henry L Tosi and Neal P. Mero, The Fundamentals of Organizational Behavior: What Managers Need to Know (Malden, Massachussetts: Blacwell Publishing, 2003).
Ian Brooks, Organisational Behaviour: Individuals, Groups, and Organisations, 3rd Edition (Delhi: Dorling Kindersley, 2006).

Joko Widodo, Analisis Kebijakan Publik, (Jakarta: Bayumedi, 2008).

M. Afzalur Rahim, Managing Conflict in Organizations, 4th Edition (New Jersey: Transaction Publishers, 2011).

Muhamad Haripin. 2013. Reformasi Sektor Keamanan Pasca Orde Baru.

Moore, Christopher W. 1996. The mediation process: practical strategies for resolving conflict. Second edition. San Francisco: Jossey-Bass.

Noong Muhajir, Metodologi Penelitian Kualitatif (Yogyakarta: Rake Sarasin, 2000), 341.

Consuelo G. Sevilla, dkk.,Pengantar Metodologi Penelitian (Jakarta: UI Press, 2006), 73-76.

Joseph A. Maxwell, Qualitative Research Design an Interactive Approach (London, Sage Publication, 2005), Koentjaraningrat, Metode-metode Penelitian Masyarakat cet. ke-14(Jakarta: Gramedia, 1997).

Philip Pettit, Republicanism: A Theory of Freedom and Government, 2002, Clarendon Press, Oxford.

Undang-Undang Republik Indonesia Nomor 17 Tahun 2013 Tentang Organisasi Kemasyarakatan. 

